\title{
Sammenslutningens kunst: Om føderalisme hos Johannes Althusius og Hannah Arendt
}

\author{
Benjamin Ask Popp-Madsen
}

Indledning

\begin{abstract}
"We cannot foretell the next steps of human history, but the alternatives seem to be clear. The resurgent problem of how to organize politically will be solved by adopting either forms of empires or federations" (Arendt, 2007: 371, min kursivering).
\end{abstract}

Med disse ord afsluttede Hannah Arendt i 1944 hendes evaluering af det europæiske statssystems fremtid i lyset af totalitarismen. Da dette system af selvstændige nationalstater ikke var i stand til at sikre borgernes sikkerhed, endsige deres velfærd og demokratiske selvbestemmelse, er det i Arendts evaluering dømt til en tilværelse på historiens losseplads. Alternativet til nationalstatssystemet består for Arendt i et simpelt valg: Enten vil forskellige former for imperier afløse nationalstaten, sådan som det 12 år lange tyske Tusindårsrige forsøgte, som Mussolinis italienske fascistparti prøvede eller som i Stalins kommunistiske Sovjetimperium; eller også vil det stadig genkomne problem vedrørende hvordan man skal organisere sig politisk, blive løst gennem føderationen. Føderationen, i Arendts tidlige evaluering, er således både et alternativ til nationalstaten og dens strenge hierarki mellem inklusion og eksklusion, dens statiske dominans over territorium og folk, samt statens manglende evne til at løse grænsekonflikter uden vold. Samtidig er føderationen også en alternativ måde dynamisk at forøge, forstørre og forandre territorium, folk og grænser på, da føderationen modsat imperiet ikke udvider sig via krig, besættelse og belejring. Som Montesquieu bemærkede i Om lovenes and 
(1748), er det føderale organiseringsprincip måden hvorpå republikken kan vokse sig større uden vold, men gennem sammenslutning og magtdeling.

I denne artikel vil jeg kigge nærmere på hvad en sådan føderal politisk organisering indeholder, hvilke værdier, der kan forbindes med føderationen som politisk form i forhold til staten, og i hvilken forstand, at føderationen kan forstås som et særligt demokratisk fællesskab. Som altid når der diskuteres politiske former (stat, polis, føderation, imperium, arbejderråd, bystat, fagforening, bureaukrati etc.), skal man være påpasselig med hvilken generalitet, man udtaler sig. Der findes således ikke én idealtypisk, transhistorisk 'føderation' fra hvilken en række normative og generelle principper kan udledes. Ej heller findes der én oprindelig historisk eller empirisk føderation, fra hvilken andre føderationer kan siges at være variationer af eller afvigelser fra. Endnu mere absurd ville det være at hævde, at føderationer altid medfører et særligt demokratisk fælleskab, eller at frihed, lighed, retfærdighed eller en andet ønskværdigt tilstand altid opstår i føderationer. Historisk set er der opstået monarkiske føderationer, illiberale føderationer med imperiale ambitioner samt føderationer komplet blottet for folkelig indflydelse (Cohen, 2013). Selvom der ikke findes en klart vedtaget institutionel definition af føderationen som politisk form (Riker, 2001; Diamond, 2011; Hueglin, 2011), opregnes der normalt en række positive egenskaber ved føderationen. Føderationen siges at være baseret på lighed, på grund af dens anti-hierarkiske magtdeling (Diamond, 2011: 222) samt at tilskynde til folkelig deltagelse på grund af de fødererede enheders begrænsede størrelse (Inman, 2011: 263; Kincaid, 2011: 250). Herudover fremhæves det ofte, at føderationen afløser statens udelelige suverænitet (i traditionen fra Thomas Hobbes og Jean-Jacques Rousseau) med føderale lag for selvbestemmelse og delt styring (self rule and shared rule) (Elazar, 1998: 199; Cohen, 2013). Ud fra disse institutionelle og politiske karakteristika opstår idéen således ofte om føderationen som rammen om et særligt demokratisk fællesskab, hvor de fødererede enheders størrelse muliggør en høj grad af selvbestemmelse og folkelig indflydelse, og hvor den institutionelle struktur muliggør opkomsten af flere forskellige institutioner for politisk deltagelse og interessevaretagelse. En sådan pluralistisk institutionel konstruktion - modsat statens unitære opbygning muliggør "numerous smaller arenas for democratic self-governance ... federalism offers citizens many opportunities to hold elected office, and otherwise participate in public 
affairs ... Federalism offers citizens multiple points of access to public power" (Kincaid, 2011: 248).

Fremfor at hævde, at de ovenstående positive karakteristika altid gør sig gældende ved føderale organisationsformer, vil jeg i denne artikel tage livtag med to føderale tænkere, nemlig Johannes Althusius og Hannah Arendt, for således at diskutere to distinkte visioner for føderal politik og føderationen som politisk form. Althusius skrev sit hovedværk Politica i 1603 og bliver ofte betegnet som faderen til moderne føderalisme (Gierke, 1990; Kalyvas, 2013). I Althusius' forord til Politica nævnes eksplicit (Althusius, 1995: 3-9), at skriftet er rettet imod en anden samtidig politisk tænker, nemlig Jean Bodin og hans doktrin om suverænens udelelige, uindskrænkede og gudgivne magt til at befale over sine undersåtter (Bodin, 1992), der blev umådelig indflydelsesrig under det franske, absolutistiske statsbygningsprojekt. Bodins Six livre de la republique fra 1576 betegnes således som ophav til den moderne doktrin om statssuverænitet (Franklin, 1973; Skinner, 1978: 286-290). Den første (tidligt) moderne politiske afhandling om føderationen er således rettet imod statssuverænitet som begreb og staten som politisk form. Det er derfor vigtigt at bemærke, at da Bodin og Althusius i overgangen mellem det 16. og 17. århundrede skrev deres værker om henholdsvis stat(suverænitet) og føderation, var staten ikke den altoverskyggende, hegemoniske politiske form, som den trods alt stadig er i dag. At følge Althusius' argumenter for føderationen, hvilket politisk liv, der udspiller sig i føderationen samt dens overlegenhed i forhold til staten, er derfor at undersøge en vej - en politisk organiseringsform -, der ikke blev afprøvet til fulde i moderniteten. Eller mere polemisk i schmittiansk ${ }^{1}$ forstand: Føderationen tabte til staten som politisk organisationsform (Cohen, 2013; Kalyvas, 2013; Klusmeyer, 2009: 53), og med dette nederlag mistedes også centrale elementer af den føderalistiske forestillingsverden og dens i forhold til staten alternative opfattelse af det politiske fællesskab samt alternative begrundelserne for konstitueringen af politiske organisationsformer. Ved at gå tilbage til Althusius - til dette vigtige historiske moment, hvor stat og føderation som

\footnotetext{
${ }^{1}$ Carl Schmitt udviklede i Det politiske begreb idéen om, at begreber bliver politiske begreber, idet de er polemiske, dvs. i det omfang, at begreberne vil modbevise, modargumentere og tilbagevise andre begreber (Schmitt, 2002).
} 
modsætninger debatteres indgående - og diskutere hans føderale vision, vil det blive tydeligt hvilke politiske værdier en ikke-statslig føderation ${ }^{2}$ kan indeholde.

På trods af Althusius’ forholdsvis marginale indflydelse på det 20. århundredes politiske tænkning ${ }^{3}$, og på trods af, at Hannah Arendt ikke nævner Althusius én eneste gang i hendes forfatterskab, er Arendt alligevel én af det 20. århundredes klareste eksponenter for et forsøg på at genfortolke føderationen og dens grundlæggende modsætningsforhold til staten. Som det indledende citat illustrerer og som hendes gennemgribende kritik af suverænitetsbegrebet - både det monarkiske hos Thomas Hobbes (Arendt, 2012: 165-167) og det folkelige hos Jean-Jacques Rousseau (Arendt, 2012: 73-75) - bevidner, så var Arendt gennem sit forfatterskab på udkig efter alternative organisationsformer til den suveræne stat. Føderationen, i Arendts analyse, er et sådan alternativ.

For at diskutere dette føderale alternativ til den suveræne stat, vil artiklen vil være struktureret i tre dele: Først introduceres Althusius’ føderale vision med særlig fokus på modsætningsforholdet til staten som politisk form. Dernæst sættes denne føderale vision i dialog med Arendts forestillinger om føderationen, og endelig - i artiklens sidste afsnit - udledes to centrale føderale politiske principper, nemlig sammenslutning og selvstyre.

Johannes Althusius: Sammenslutning som føderalt princip

Quentin Skinner har i sit værk om staten og suverænitetsbegrebets opkomst, The Foundations of Modern Political Thought (1978), kaldt Althusius' Politica for "the most systematic statement of revolutionary Calvinist political thought" (1978: 341). Den revolutionære calvinistiske tænkning har sit ophav i de europæiske religionskrige fra midten af 1500-tallet og frem. Calvinisterne var oftest et religiøst mindretal i det overvejende katolske Europa, og levede derfor primært under katolske love og katolske monarker. Derfor producerede calvinistiske intellektuelle allerede meget tidligt politiske traktater

\footnotetext{
${ }^{2}$ Staten har ideologisk set 'besejret' føderationen i en sådan grad, at nutidens 'føderale' systemer i eksempelvis USA og Tyskland er 'føderale stater' (hvilket for Althusius ville være en begrebslig umulighed), dvs. at suveræniteten findes på centralt niveau og ikke hos de enkelte medlemmer. Se for eksempel Cohen 2013.

${ }^{3}$ Efter århundreder i relativ glemsel, også for interesserede i føderalisme, blev Althusius 'genopdaget' af den tyske historiker Otto von Gierke i hans storværk Political Theories of the Middle Ages (1900). Senere blev Althusius diskuteret indgående af den tysk-amerikanske forfatningshistoriker Carl Friedrich (1932), og indenfor de sidste 40 år har Althusius igen fået plads i fremstillinger omhandlende føderationens idéhistorie og modstilling til staten hos blandt andet Frederick Carney (1964), Thomas Hueglin (1979) og Patrick Riley (1976).
} 
om retten til oprør imod uretfærdige fyrster og monarkker, samt om legitimiteten af revolution og samfundsomstyrtelse (Skinner, 1978: 302-348; Walzer, 1982: 1-113; Wood, 2012: 155-161; Franklin, 1969). Sådanne teorier om retten til oprør beror dybest set på en diskussion af, hvor (i hvilket embede) eller hvad suverænitet består i. Calvinistiske radikale som de franske 'kongedræbere' (monarchomacs), Theodore Beza, Francois Hotman og Plilippe Mornay, dernæst Johannes Althusius og senere John Locke (hvis Anden afhandling om styreformen (1689), Skinner kalder for "the classic text of radical Calvinist politics" (1978: 239)), udviklede således alle varianter af argumentet om, at politiske magthavere, fyrster, konger, kejsere osv., er konstituerede instanser og embeder, og at de som sådan er blevet konstitueret af folket selv. Netop derfor har folket retten til revolution og omstyrtelse, såfremt magthaverne stopper med at handle i det fælles bedste (se for eksempel Kalyvas, 2016: 59-67) ${ }^{4}$. Suverænitet for disse calvinistiske radikale tænkere er derfor ikke lig med magthaverens absolutte befaling, som suverænitet forstås både hos Jean Bodin ${ }^{5}$, men også for en anden af statssuverænitetens mestertænkere, Thomas Hobbes ${ }^{6}$. Suverænitet består i stedet i magten og evnen til at konstituere politiske fællesskaber; suverænitet bliver for de calvinistiske radikale lig den konstituerende magt (Elazar, 1995: xlii-xliii) ${ }^{7}$.

Hvad har dette at gøre med diskussionen af føderalisme og Althusius' føderale vision? For Althusius, i hvert fald i min fortolkning, bliver føderation et institutionelt udtryk for denne folkets konstituerende magt, og dét politiske princip, at hvad, der er blevet konstitueret (kongeligt embede, fyrsteligt embede, statsoverhoved etc.), altid er underlagt og underordnet dét, der har konstitueret det. Føderationen bliver således den institutionelle måde hvorpå Althusius forsøger at modargumentere Bodin og idéen om

\footnotetext{
${ }^{4}$ En sådan teori om retten til revolution fik også afgørende indflydelse på de engelske pilgrimmes afvisning af den engelske kongemagt samt de amerikanske revolutionæres krav om selvstændighed og egen forfatning (Elazar, 1995: xxxvii).

${ }^{5}$ Den klassiske reference for bestemmelsen af Bodins suverænitetesbegeb som den øverste magt til befaling er: "Sovereignty is the absolute and perpetual power of a commonwealth ... that is, the highest power of command" (1992: 1).

${ }^{6}$ Hobbes følger i Leviathan Bodins grundlæggende forestilling af suverænitet som befaling: "law is a command, and a command consisteth in declaration or manifestation of the will of him that commandeth" (1994: 177).

${ }^{7}$ Begrebet 'den konstituerende magt' har været underlagt stigende interesse de sidste 10 år, siden udgivelsen af antologien redigeret af Martin Loughlin and Neil Walker, The Paradox of Constitutionalism: Constituent Power (Oxford: Oxford University Press, 2007), og Andreas Kalyvas' Democracy and the Politics of Extraordinary: Max Weber, Carl Schmitt, Hannah Arendt (Cambridge: Cambridge University Press, 2008).
} 
monarkens absolutte, udelelige og gudsgivne, suveræne ret til at befale. Lad os kigge nærmere på Althusius’ værk.

Selve værket Politica er opbygget således, som Althusius forestiller sig føderationen være opbygget. Teksten følger sammenslutningen og sammenkoblingen af familier, foreninger (lav, gilde) og landsbyer til det punkt, hvor disse sammenslutninger udgør en by. Dernæst følges sammenslutningen af byer til regioner og provinser, og endelig følges sammenslutningen af provinser til en samlet føderation. Althusius' føderation er således grundlæggende opbygget gennem en kontinuerlig og frivillig indgåelse af pagter og sammenslutninger; endda i en sådan grad, at Politicas først kapitel indledes med disse bemærkelsesværdige linjer:

\footnotetext{
"Politics is the art of associating men for the purpose of establishing, cultivating, and conservating social life among them. Whence it is called 'symbiotics'. The subject matter of politics is therefore association, in which the symbiotes pledge themselves each to the other, by explicit or tacit agreement, to mutual communication of whatever is useful and necessary for the harmonious exercise of social life" (Althusius, 1995: 17).
}

Politik er sammenslutningens kunst med det formål at leve et harmonisk liv i fællesskab. Føderal politik i Althusius' evaluering er kendetegnet ved gentagen sammenslutning af politiske fællesskaber, hvorved nye muligheder for samarbejde og samliv opstår. De sammensluttende parter er "co-workers, by the bond of an association and uniting agreement, communicate among themselves whatever is appropriate for a comfortable life of soul and body. In other words, they are participants or partners in a common life" (Althusius, 1995: 19). Det bemærkelsesværdige i disse linjer er den alternative politiske forestillingsverden, en sådan sammenslutningens politik beskriver. Politik indstiftes her ikke af retningsløse individer i naturtilstanden udenfor samfund og historie eller gennem gudsindsatte monarker; politik er ikke et middel til at tøjle frygt, usikkerhed, krig og menneskets indbyggede drift for selvhævdelse og ære. Indstiftelsen af samfundet er ej heller en måde at garantere sikkerhed og beskyttelse på, med et tab af frihed til følge. Politik for Althusius derimod at slutte sig sammen, forbinde sig, og forene sig i et samarbejdende, fælles liv. Politik er selve den handling og den proces, hvorigennem fællesskaber slutter sig sammen og indgår gensidige, bindende aftaler om at udvide samarbej- 
det, indlemme nye fællesskaber i føderationen eller forandre de grundlæggende regler for fællesskaber i lyset af politiske, social og historiske forandringer. Føderalistisk politik er således baseret på foedus; etymologisk stammer føderalisme fra det latinske foedus, i betydningen pagtindgåelse (covenant) eller sammenslutning. Politiske institutioner kan således kun konstitueres legitimt gennem frivillig pagtindgåelse, gennem aftaler mellem gensidigt fødererende parter $^{8}$. Som Daniel Elazar klart har udtryk det, er en føderal sammenslutning baseret på en "pact between peoples or parties having independent and sufficiently equal status, based upon voluntary consent and established by mutual oaths or promises ... covenant expresses the idea that people can freely create communities and polities, peoples and publics" (2011: 3-4, min kursivering). Føderalisme - forstået som pagtindgåelse, eller som 'the art of association' som formuleret af Althusius - indeholder således idéen om, at nye politiske systemer og fællesskaber kan skabes, og at nye offentligheder og folk kan dannes.

For at forstå denne idé om føderalisme som konstitueringen af nye politiske fællesskaber og former (føderalisme som konstituerende magt), så lad os kigge nærmere på hvorledes Althusius forestiller sig føderationen være opbygget om og hvorledes dette relaterer sig til modsætningsforholdet til Bodins statssuverænitet.

Althusius forestiller sig som sagt, at føderationen består af kontinuerligt højere lag af sammenslutninger, konstitueret fra neden. Det er således familierne, foreningerne og arbejdsfællesskaberne, der aktivt slutter sig sammen i byer; det er de sammensluttede byer der frivilligt slutter sig sammen til regionale sammenslutninger, og det er de forenede regioner og provinser, der går sammen om at skabe det øverste føderale niveau. Det politiske og administrative niveau i det øverste føderale niveau (hvad Althusius også kalder 'den universelle sammenslutning'), i regionerne, provinserne og byerne har ikke individerne som medlemmer, hvilket betyder, at disse politiske og administrative niveauer ikke har direkte befalingsret over individerne, som hos både Bodin og Hobbes. For disse er essensen af den politiske sammenslutning at skabe først en afstand mellem suveræn og subjekt, og dernæst en direkte hierarkisk relation mellem disse. Althusius' føderalisme er derimod korporatistisk i den forstand, at individerne forestilles at indgå i en række selvfølgelige, organiske relationer knyttet til familie- og arbejdsliv i det lokale

\footnotetext{
${ }^{8}$ Den åbenlyse indsigelse, at én af statssuverænitetens mest markante teorier, Hobbes' Leviathan, også er baseret på en frivillig kontrakt, vil blive diskuteret i næste afsnit omhandlende Arendt.
} 
miljø. Det er disse lokale miljøer, der har individerne som medlemmer, og som danner rammen for identitet, samvær og ikke mindst politisk deltagelse og selvbestemmelse. På dette punkt er Althusius en premoderne aristoteliker ${ }^{9}$, og adskiller sig således for eksempel de amerikanske føderalister. Det er som bekendt ét af hovedargumenterne i The Federalist Papers og således også i moderne føderalistisk tænkning, at det nye føderale hovedsæde må have individer som medlemmer ved siden af delstater således, at det føderale niveau har direkte befalingsret over individerne (Hamilton et al, 1961: 105). En sådan direkte befalingsret er ikke mulig i Althusius' føderation af den grund, at føderationen kontinuerlig er konstitueret nedefra og op, således at lokale niveauer har konstitueret de regionale niveauer, og de regionale niveauer igen har konstitueret det føderale niveau. Det konstituerende folk er derfor altid overordnet og højerestående dets institutioner, netop fordi de har konstitueret dem:

\begin{abstract}
"For the commonwealth or realm does not exist for the king, but the king and every other magistrate exist for the realm and the polity. By nature and circumstance the people is prior to, more important than, and superior to its governors, just as every constituting body is prior and superior to what is constituted by it" (Althusius, 1995: 93, min kursivering).
\end{abstract}

Det centrale, vejledende princip i Althusius' føderalisme er således, at den konstituerende part beholder herredømmet over dets konstituerede institutioner. Som føderationen udvider sig, indlemmer flere medlemmer og inkorporerer flere politiske fællesskaber, fremmedgøres magten ikke til disse nye institutionelle niveauer. Den politiske ret til at associere og dissociere fratages ikke de lokale politiske fællesskaber, netop fordi de besidder den konstituerende, magt fordi de mestrer 'the art of association'. Rent historisk brugte Althusius og andre samtidige radikale tænkere denne tankefigur til at argumentere for, at alle indstiftede institutioner måtte være underlagt folkets vilje og kontinuerlige revision, hvorfor retten til oprør måtte være legitim. Eksempelvis skrev den calvinistiske revolutionære Philippe Mornay i 1576, i et forsvar for oprør imod den franske kongemagt, at "since kings, then, are created by the people, it seems to follow

\footnotetext{
${ }^{9}$ For en modstilling mellem premoderne, aristotelisk teori om politiske sammenslutninger og om moderne, individbaserede sammenslutninger, se Noberto Bobbio Thomas Hobbes and the Natural Law Tradition.
} 
that the people as whole is greater than the king. This is an implication of the term itself, since one who is created by another is considered his inferior" (Mornay, 1969: 161). Men princippet om, at folket som konstituerende magt er overordnet dets konstituerede institutioner, har ikke kun historisk relevans i forhold til at forstå argumenter for og imod monarki i den tidlige europæiske modernitet, men har også en række begrebslige konsekvenser, hvis princippet sammenholdes med forholdet mellem folk og institutioner i statsteorien hos Bodin og Hobbes.

For både Bodin og Hobbes findes politik kun gennem indstiftelsen af en suveræn med befalingsret over territorium og folk. Om end denne befalingsret har sit ophav i guddommelig legitimitet eller hos isolerede individer i et ubeboeligt vildnis, så opstår politik først igennem afhændelse og fremmedgørelsen af magten. I det øjeblik, at politik opstår, bliver individerne magtesløse. For Althusius, derimod, og for den føderale vision, han fremlægger, findes politik i stedet i autonome og organiske politiske fællesskaber udenfor konstituerede institutioner. Disse politiske fællesskaber eksisterer uden behovet for embedsmænd, dommere, konger, fyrster og andre myndighedspersoner, hvorimod sådanne embeder umuligt kan eksistere uden folket.

\footnotetext{
"Whence it follows that the people can exist without a magistrate, but a magistrate cannot exist without a people, and that the people creates the magistrate rather than the contrary. Therefore, kings are constituted by the people for the sake of the people, and are its ministers to whom the safety of the commonwealth has been trusted" (Althusius, 1995: 123).
}

Det er således klart, ud fra denne beskrivelse af forholdet mellem folk og suveræn, mellem konstituerende magt og konstitueret institution, at der eksisterer et autonomt politisk liv før, under og ved siden af de konstituerede institutioner, der er overordnet og højerestående disse. Det forholder sig helt omvendt for statstænkerne, hvilket Althusius er ganske klar over. "Bodin clamors that these rights of sovereignty cannot be attributed to the realm or to the people", klargør Althusius, og tydeliggør hans alternativ til Bodin:

"I know that in the common opinion of teachers they are to be described as belonging to the prince or supreme magistrate ... I am not troubled by the clamors of Bodin, nor the voices of others who disagree with me ... the ownership and usufruct of these 
rights have no other place to reside if they do not remain with the total people" (Althusius, 1995: 6-7).

Der er således en klar sammenhæng mellem Althusius' bestemmelse af politik som sammenslutning og pagtindgåelse, hans føderale indretning af det politiske system og hans prioritering af den konstituerende magt over konstituerede institutioner. Føderationen, foedus, er det institutionelle udtryk eller den institutionelle ramme for pagtindgåelse og kontinuerlig sammenslutning. Føderationen er således i Althusius’ fortolkning den politiske form, den institutionelle struktur, der fremkommer igennem folkelig forbindelse og sammenslutning. At en sådan kontinuerlig sammenslutning er mulig igennem udvidelse og forøgelse af det politiske system, er funderet på det simple politiske princip, at de konstituerende enheder er overordnet deres institutionelle frembringelser. Althusius’ føderation genskaber således fortløbende mulighederne for at indgå pagter, sammenslutninger og kontrakter.

I det følgende vil jeg kigge nærmere på Hannah Arendts føderale vision, hvor centrale elementer fra Althusius' føderalisme kan genfindes.

\section{Arendt: Løftet som føderalt princip}

Historisk skitserer Althusius sin føderale vision omkring statssystemets opståen og $\mathrm{i}$ modsætning til statens mest indflydelsesrige forsvarsskrift (Bodin). I modsætning hertil leverer Arendt sin føderale vision på det tidspunkt, ifølge hendes egen evaluering, hvor statssystemet begynder at krakelere. Althusius ser således føderationen som et alternativ til staten i dennes spæde begyndelse; Arendt ser føderalismen som et alternativt organisationsprincip ved statens afslutning.

Arendts idéer om føderalisme har indtil fornyligt været et relativt marginalt emne i den ellers evigt voksende Arendt-sekundærlitteratur, primært fordi disse idéer er spredt ud over tidlige essays som Zionism Reconsidered (1944), To Save the Jewish Homeland (1948) og The Aftermath of Nazi Rule (1950) samt får en ganske usystematisk behandling i værket Om revolution (1963), der som bekendt behandler den amerikanske revolutionære tradition og derfor også byder på en række føderale indsigter. I sekundærlitteraturen har særligt Klusmeyer (2007) banet vejen for en ny opmærksomhed omkring denne del af Arendts forfatterskab (se for eksempel Rubin, 2015; Selinger, 2016). Disse 
fortolkninger af Arendts føderalisme deler et historiografisk udgangspunkt, der klargør hvorledes Arendts tanker om føderationen var en konsekvens af totalitarismens uhyrligheder og nationalstatens rolle i dennes opkomst. Det demonstreres bl.a. hvorledes Arendts negative vurdering af nationalstaten får hende til at afvise en jødisk enhedsstat $i$ Israel i forhold til en multietnisk føderation (Rubin, 2015: 394) samt hvorledes Arendt i artikler og ved offentlige arrangementer efter 2 . verdenskrig deltog aktivt $\mathrm{i}$ debatten om europæisk rekonstruktion med fokus på føderationen som alternativ til statssystemet (Selinger, 2016: 5-15). Disse er åbenlyst vigtige indsigter, der bidrager til at klargøre, at Arendt - ligesom Althusius, dog under forskellige historiske omstændigheder - ser føderationen og staten som politiske modsætninger. Igennem hele hendes forfatterskab har Arendt været ekstremt kritisk overfor suverænitet og herredømme som politiske grundkategorier, fordi disse eliminerer pluralitet og frihed (Arendt, 2008: 54-62;1993: 143172). I Arendts vurdering af den amerikanske revolution hedder det derfor, at den "største amerikanske opfindelse" var "erkendelsen af, at inden for sfæren for menneskelige anliggender er suverænitet og tyranni det samme" (2012: 149).

I det følgende vil jeg bidrage til denne voksende litteratur om Arendts føderalismebegreb ved at gå anderledes begrebsligt til værks og relatere føderation til Arendts idé om den konstituerende magt. Også her, skal det vise sig, deler Arendt og Althusius centrale elementer.

I min vurdering leverer Arendt to politisk teoretiske hovedværker, nemlig Menneskets vilkår (1958) og Om revolution $(1963)^{10}$. Om end arendtianske kernebegreber som politisk handling, natalitet, pluralitet, nye begyndelse og frihed er styrende for begge fremstillinger, er der dog sket et skifte i betoningen af det individuelle og kollektive element i politisk handling. I Menneskets vilkår fremstår politisk handling som individernes mulighed for at blive set og hørt i den offentlige sfære, som muligheden for at gøre sig gældende blandt ligemænd. Fællesskabet er ingenlunde fraværende, idet der skal være et politisk fællesskab, hvorigennem pluralitet kan erfares, men fokus er på den politiske sfære som en scene, hvorpå individet kan træde frem (Arendt, 1998: 72-74). I Om revolution er det kollektive element ved politisk handling i forgrunden, idet politik

\footnotetext{
10 Arendts andre hovedværker anser jeg enten for værende af mere filosofisk karakter (The Life of the Mind (1971)), eller af mere tematisk karakter (om totalitarisme i The Origins of Totalitarianism (1951), og om ondskab og holocaust i Eichmann in Jerusalem (1963)).
} 
forstås som den kollektive indstiftelse af nye politiske former og institutioner ${ }^{11}$. Arendt forsøger her at finde et svar på hvad, der kan legitimere og stadfæste opkomsten af nye politiske systemer, når hverken gud eller naturen kan regnes som samfundslivets ultimative grund. I de amerikanske kolonialister og revolutionæres politisk praksis finder hun et princip, der præcis tjener dette formål, nemlig - ligesom Althusius - evnen til at forbinde sig og slutte sig sammen gennem pagter, aftaler og konventer. Hvor Althusius' føderalisme er baseret på 'the art of association', er Arendts ditto baseret på "det at give og holde løfter, der i politikkens sfære meget vel er den højeste menneskelige evne" (Arendt, 2012: 172, min kursivering).

Som billede på denne evne til at afgive og holde løfte, fortæller Arendt parablen om de engelske pilgrimme ombord på skibet The Mayflower i 1620 og den sammenslutning, de indgik på skibet, før de ankom til den nye verden. Pilgrimmene valgte ifølge Arendt "at slutte sig sammen i et 'civil, politisk organ', der, idet det udelukkende var holdt sammen af det gensidige løftes styrke ... angiveligt var stærkt nok til at 'vedtage, konstituere og udforme' alle nødvendige love og regeringsorganer" (Arendt, 2012: 163164, min kursivering). Det gensidige løfte skaber således, i Arendts evaluering, et politisk fællesskab, der dernæst er i stand til udforme love og konstituere regeringsorganer. Det er ikke således, som hos Bodin og Hobbes, at det politiske fællesskab kun kan udtrykkes via lov (retspositivisme) eller gennem suverænen. Der kan skabes et autonomt politisk liv før suverænens indstiftelse og institutionalisering, netop gennem løftet og sammenslutningen. "Eftersom de koloniale pagter oprindeligt havde været udformet uden nogen reference til konger eller fyrster", forsætter Arendt, "var det, som om revolutionen frigjorde den iboende kraft i at indgå pagter og udforme forfatninger" (2012: 164). Det således ved at slutte sig sammen og forbinde sig, ved at vedtage fælles forfatninger, at nye politiske fællesskaber, institutioner og systemer kommer til verden. Det er ved at slutte sig sammen i et konstituerende foellesskab, at magten kan holdes ved lige og undgås at afhændes og fremmedgøres til suverænen. Aftalerne og pagterne mellem de engelske pilgrimme blev ifølge Arendt indgået uden reference til kongelige herredømme og uden at opdele samfundet i regerende og regerede. Den eneste legitimitet disse pilgrimme påkaldte sig, var retten til at konstituere (2012: 62-64). Arendt påstår

\footnotetext{
11 For dette skift i Arendts opfattelse af politisk handling og frihed, se for eksempel Kalyvas, 2008: 200-210.
} 
derfor, at det er i den menneskelige evne til at fremsætte, indgå og overholde løfter, at menneskets 'verdensskabende' kapacitet skal findes:

\begin{abstract}
"Således er det at binde sig til hinanden og afgive løfter til hinanden, at slutte sig sammen og indgå pagter de midler, hvormed magten holdes ved lige ... Der er et element af menneskets verdensskabende evne i den menneskelige evne, det er at kunne indgå og holde løfter” (Arendt, 2012: 171).
\end{abstract}

Det er her naturligt at tage fat på den indsigelse allerede nævnt i note 8, at statssuverænitetens mest paradigmatiske teori, nemlig Hobbes' Leviathan, også baserer suverænitetens ophav på indgåelsen af en frivillig kontrakt. Ved at modstille Hobbes’ kontrakt og Arendts løfte, vil det blive tydeligere hvad Arendts føderale vision indeholder. Arendt diskuterer indgående forskellene mellem hvad hun kalder Hobbes' 'social kontrakt' og Lockes 'gensidige kontrakt' ${ }^{12}$. I Lockes kontrakt - som løftet er modeleret over - slutter menneskene "sig sammen for at danne et fællesskab, er baseret på reciprocitet og forudsætter lighed; dens reelle indhold er et løfte, og dens resultat er et 'samfund' eller cosociation". Omvendt er det "åbenlyst, at den sociale kontrakt, der kræver overgivelsen af magten til staten og samtykket til dens regeren, in nuce indeholder både princippet om absolut herredømme, om et absolut magtmonopol 'til at indgyde ærefrygt i dem alle' (Hobbes) ... og det national princip, ifølge hvilket der må være en repræsentant for nationen som helhed, og hvor staten forstås som inkarnationen af alle statsborgeres vilje" (Arendt, 2012: 166, 167). Problemet med Hobbes' kontrakt og det forhold, der diskvalificerer denne til kunne virke som gensidigt løfte er, at magten afhændes og fremmedgøres hos Hobbes samt, at hierarki og underkastelse indstiftes. Kontrakten er ydermere et moment, en enkeltstående begivenhed, ikke en kontinuerlig praksis. Når kontrakter indgås på denne måde, hævder Arendt, "mister de deres bindende magt og bliver selvødelæggende" (2008: 244).

Spørgsmålet er nu hvorledes Arendt forbinder hendes idé om løftets skabende og konstituerende kraft, dvs. det forhold, at det gensidige løfte er ophav til og skaber politiske fællesskaber før og udenfor de politiske institutioner, med idéen om føderalisme. Arendt læser pagten indgået ombord på skibet Mayflower som et billede på den generel-

\footnotetext{
${ }^{12}$ Husk på, at Locke blev opregnet af Skinner som tilhørende samme calvinistisk-radikale tradition som Althusius.
} 
le politiske praksis blandt de engelske kolonialister fra 1620 og indtil Uafhængighedserklæringen i 1776 og den amerikanske forfatning i 1789. Overalt blandt de 13 nye Nordamerikanske kolonier, der senere blev til de 13 selvstændige stater, som via 1789forfatningen sluttede sig sammen til en fælles union, blev der indgået pagter, afholdt konventer og konstitueret nye rammer for politisk deltagelse. Ligesom Althusius' forestillede sig, at føderationen var baseret på sammenslutning og pagtindgåelse fra neden og op, så læser Arendt amerikansk kolonihistorie som ophav til "et helt nyt begreb om magt og autoritet" (Arendt, 2012: 162), hvor lokale politiske enheder kan kombinere sig og slutte sig sammen uden at afhænde deres ret til selvbestemmelse. En 'udvidet republik' for at tale med James Madison eller en 'føderal republik' som hos Montesquieu, kan således opstå via de lokale enheders - "distrikter, amter, townships (selvstyreenheder på niveauet under amterne)" (2012: 161) - kontinuerlige sammenføjning og forbindelse. Det er afgørende for Arendt - ligesom det var for Althusius - at fastholde, at retten til at slutte sig sammen og konstituere nye politiske fællesskaber, retten til at indgå politiske løfter, findes hos de lokale og elementære politiske enheder. Kun ved "at bevare disse organers magt usvækket" (2012: 161), bliver en egentlig føderal sammenslutning mulig. Det er igennem en sådan forståelse af det føderale projekt, at føderationen kan siges at være rammen om et særligt demokratisk fællesskab:

\footnotetext{
"Med andre ord indeholder den gensidige kontrakt, hvor magten er konstitueret ved hjælp af et løfte, in nuce både det republikanske princip, ifølge hvilket magten residerer i folket, og hvor en 'gensidig underkastelse' gør tanken om en hersker til en absurditet ... og det føderale princip, princippet om 'et stadig voksende Commenwealth' (som Harrington kaldte sit utopiske Oceana), ifølge hvilket konstituerende politiske organer kan slutte sig sammen og indgå i vedvarende alliancer uden at miste deres identitet" (Arendt, 2012: 167).
}

Politiske systemer baseret på løfte og sammenslutning indeholder således to principper, et republikansk princip om selvbestemmelse og et føderalt princip om sammenslutning. Det republikanske princip tilsiger til dels, at politiske fællesskaber kan indstiftes uden, at en suveræn hersker og dertilhørende hierarki fremkommer; og til dels, at selvbestemmelse foregår lokalt, hvor folk kan deltage gennem deliberation, beslutning og delegation. Det føderale princip indeholdt i løftet tilsiger, ifølge Arendt, at republikken - 
og dermed selvbestemmelsen - kan vokse sig større, og dermed møde nye udfordringer og klare forandrede vilkår, via sammenslutning og pagter. Kort sagt, via foedus.

Arendts føderale vision er således "grundlæggelsen af et nyt statslegeme, en ny form for republikansk styreform, der skulle hvilke på 'elementarrepublikker' på en sådan måde, at centralmagten ikke berøver de konstituerende organer deres oprindelige magt til at konstituere" (2012: 263). Denne føderale vision om lokale, konstituerende 'elementarrepublikker', der via kombination og forbindelse skaber nye politiske institutioner uden derved at overdrage magten til disse, tematiserer således - ligesom som hos Althusius - forholdet mellem den konstituerende magt og de politiske institutioner. Føderationen, i Arendts analyse, er den politiske form, hvorigennem den konstituerende magt - løftet som verdensskabende kapacitet - kan holdes live, kan genfremsættes, genforhandles, omstødes og forandres, og hvor disse ændringer, genforhandlinger og konstituerede institutioner ikke annullerer og ophæver den konstituerende magt. Arendts føderale vision deler således med Althusius' ditto det politiske princip, at konstituerede institutioner må være politisk overordnet og kontrolleret af deres konstituerende ophav.

\section{Føderale principper: Sammenslutning og selvbestemmelse}

Som opsummering og konklusion vil jeg kort opridse lighederne mellem Johannes Althusius’ og Hannah Arendts føderalisme, for dernæst på baggrund heraf opstille, hvad jeg antager for værende de to centrale principper for føderal politik, en sådan sammenligning indeholder.

Enhver sammenligning på af to tænkere med 350 års mellemrum, hvor den senere tænker ikke nævner den tidligere med et enkelt ord gennem sit forfatterskab, skal være ekstremt påpasselig med hævde påvirkning, indflydelse eller slægtskab mellem disse tænkere ${ }^{13}$. Jeg påstår derfor ikke, at Arendt 'viderefører' Althusius' teori om føderationen, ej heller, at disse tænkere 'deltager' i en distinkt føderalistisk 'tradition'. Endvidere påstår jeg ikke, at den empiriske føderation altid vil inkarnere de principper og værdier, som Althusius og Arendt tilskriver føderationen i deres vision. Althusius er på mange måder en premoderne tænker for hvem naturlige korporationer og familier udgør individernes naturlige fællesskaber; Arendt derimod tematiserer direkte, hvordan politiske

\footnotetext{
13 For den klassiske kritik af denne tankemåde, se Skinner 1969 (2002).
} 
systemer kan grundlægges, når 'naturlighed' (gud, natur, prædestination) har forladt den politiske sfære.

Hvad jeg dog vil påstå er, at Althusius og Arendt, på trods af deres forskelle, tematiserer en række problemer ved staten som politisk form, begge ligger vægt på den konstituerende magt $\mathrm{i}$ form af sammenslutningen (Althusius) og løftet (Arendt), og at føderation - i Althusius' og Arendts fortolkning - gennem forbund og alliancer, forbindelser og koalitioner, kan forhindre, at magten og retten til at slutte sig sammen og konstituere nye politiske institutioner ikke fremmedgøres. For Althusius diskuteres dette sidste forhold begrebsligt, nærmest logisk, via argumentet om, at et hierarkisk forhold eksisterer mellem det konstituerende ophav og dets institutioner. Dette argument modstilles Bodin argument for statssuverænitet og suverænens udelelige, uindskrænkede magt. For Arendt bliver føderationen også den politiske form, hvor magten til at konstituere ikke bliver momentan og ikke afhændes (som hos Hobbes), og hvor nye politiske 'verdener' kan skabes.

Det er således muligt at opstille to principper for føderal politik, som Althusius og Arendt forstår denne politikform, nemlig selvbestemmelse og sammenslutning. Føderalisme i den althusianske og arendtianske variant beror på lokal, folkelige selvbestemmelse i 'elementarrepublikkerne', hvorigennem det republikanske ideal om den lille republik som rammen om demokrati bekræftes. Til dette er koblet princippet om sammenslutning, hvor lokale enheder sammenslutter sig i regionale forsamlinger, og hvor regionale forsamlinger igen kordinerer og samarbejder i central konventer. Princippet om sammenslutning fra neden er således et alternativ til imperiets underlægning af fremmed territorium samt statens magthierarki. Sammenslutningen som føderalt princip siger også noget hvad politik er for Althusius og Arendt. Politik er ikke interessevaretagelse indenfor allerede vedtagne love og spilleregler; politik er derimod at slutte sig sammen og indgå løfter for herigennem skabe noget nyt. Politik gennem sammenslutning og løfteindgåelse er at ændre, forbedre, tilføre og tilføje (amendment) noget nyt til det politiske system. Det er måske i denne betydning, at Arendts påstand "om den tætte sammenhæng mellem revolutionens ånd og føderationens princip” (Arendt, 2012: 262) skal forstås. Hvad føderationen muliggør, ifølge Althusius og Arendt, er nemlig, at den konstituerende magt kan komme til syne; at det er folket - forsamlet lokalt, regionalt og centralt - der har magten over dets institutioner og ikke omvendt. 
Litteratur

Althusius, J. (1995) Politica, Indianapolis: Liberty Fund.

Arendt H. (2007) The Jewish Writings, New York: Schocken Books.

Arendt H. (2008) Menneskets vilkår, København: Gyldendal.

Arendt H. (2012) Om Revolution, Aarhus: Forlaget Klim.

Bobbio, N. (1993) Thomas Hobbes and the Natural Law Tradition, Chicago: University of Chicago Press.

Bodin, J. (1992) On Sovereignty: Four Chapters From the Six Books of the Commonwealth, Cambridge: Cambridge University Press.

Cohen, J. (2012) 'Federation'. In Political Concepts 1, no. 1, 2013. Accessed February 5th, 2016. http://www.politicalconcepts.org/issue1/federation/

Diamond, M. (2011), 'The Ends of Federalism'. In: Federalism, Vol. 1, 219-40, London: Sage Publications.

Elazar, D. (1995) 'Althusius' Grand Design for a Federal Commonwealth'. In: Carney, F (ed.): Johannes Althusius' Politica, Indianapolis: Liberty Fund..

Elazar, D. (1998) Constitutionalizing Globalization: The Postmodern Revival of Confederal Arrangements, New York: Rowman \& Littlefield Publishers.

Elazar D. (2011) 'The Political Theory of Covenant: Biblical Origins and Modern Developments'. In: Federalism, Vol. 1, 1-28, London: Sage Publications.

Franklin, J. (1969) Constitutionalism and Resistance in the 16th Century, New York: Pegasus.

Franklin J. (1973) Jean Bodin and the Rise of Absolutist Theory, Cambridge: Cambridge University Press.

Gierke, O. (1990) Community in Historical Perspective, New York: Columbia University Press.

Hamilton, A., Madison, J., \& Jay, J. (1961) The Federalist Papers, New York: Signet Classic.

Hobbes, T. (1994) Leviathan, Indianapolis: Hackett Publishing.

Hueglin, T. (2011) 'Federalism at the Crossroads: Old Meanings, New Significance'. In: Federalism, Vol. 4, 333-352, London: Sage Publications.

Inman, R. (2011) 'Federalism's Values and the Value of Federalism'. In: Federalism, Vol. 1, 259-92, London: Sage Publications.

Kalyvas A. (2008) Democracy and the Politics of the Extraordinary Max Weber, Carl Schmitt, and Hannah Arendt, Cambridge: Cambridge University Press.

Kalyvas A. (2013) 'Constituent Power'. In: Political Concepts 3, no. 1. Accessed February 5, 2016.

http://www.politicalconcepts.org/constituentpower/.

Kalyvas A. (2016) 'Rethinking 'Modern' Democracy: Political Modernity and Constituent Power'. In: Wagner, P. (ed.) The Trouble with Democracy: Political Modernity in the $21^{\text {st }}$ Century, Edinburgh: Edinburgh University Press. 
Kincaid, J. (2011) 'Values and Value Tradeoffs in Federalism'. In: Federalism, Vol. 1, 241-258, London: Sage Publications.

Klusmeyer, D. (2010) 'Hannah Arendt's Case for Federalism'. In: Publius: The Journal of Federalism 40, no. 1: 31-58.

Loughlin, M. \& Walker, N. (2007) The Paradox of Constitutionalism: Constituent Power and Constitutional Form, Oxford: Oxford University Press.

Mornay P. (1969) 'Vindicae contra tyrannos'. In: Franklin, J. (ed.) Constitutionalism and Resistance in the Sixteenth Century, New York: Pegasus.

Riker, W. (2011) 'The Origin and Purposes of Federalism'. In: Federalism, Vol. 1, 189218, London: Sage Publications.

Rubin, G. (2015) 'From Federalism to Binationalism: Hannah Arendt's Shifting Zionism'. In: Contemporary European History, vol. 24 (3), pp. 393-414.

Schmitt C. (2002) Det Politiskes Begreb, København: Hans Reitzel.

Selinger, W. (2016) 'The Politics of Arendtian Historiography: European Federation and The Origins of Totalitarianism'. In: Modern Intellectual History, Available on CJO 2014 doi:10.1017/S1479244314000560.

Skinner Q. (1978). The Foundations of Modern Political Thought: The Age of Reformation, Vol. 2. Cambridge: Cambridge University Press.

Skinner Q. (2002) Visions of Politics: Regarding Method, Cambridge: Cambridge University Press.

Walzer, M. (1982) Revolution of the Saints: A Study on the Origins of Radical Thought, Cambridge: Harvard University Press.

Wood E. (2012) Liberty and Property: A Social History of Western Political Thought from Renaissance to Enlightenment, London: Verso Press. 